\title{
Forest and peatland fire severity assessment at Siak Regency, Riau Province using Sentinel-2 Imagery
}

Fakhri Sukma Afina ${ }^{\mathrm{a}}$, Lailan Syaufina ${ }^{\mathrm{b}}$, Imas Sukaesih Sitanggang ${ }^{\mathrm{c}}$

\author{
${ }^{a}$ Tropical Silviculture Study Program, Postgraduate School, IPB University, IPB Darmaga Campus Bogor, 16680, Indonesia \\ [+62 81294454742] \\ ${ }^{\mathrm{b}}$ Department of Silviculture, Faculty of Forestry and Environment, IPB University, IPB Darmaga Campus Bogor, 16680, Indonesia \\ ${ }^{\mathrm{c}}$ Department of Computer Science, Faculty of Mathematics and Natural Sciences, IPB University, Jl. Meranti Wing 20 Level V, IPB \\ Dramaga Campus Bogor, 16680, Indonesia
}

\section{Article Info:}

Received: 17 - 09 - 2021

Accepted: $09-11-2021$

\section{Keywords:}

Fire severity, normalized burn ratio, peatland, transboundary haze

\author{
Corresponding Author: \\ Lailan Syaufina \\ Department of Silviculture, \\ Faculty of Forestry and \\ Environment, IPB University; \\ Tel. +62-251-8626806 \\ Email: \\ lailans@apps.ipb.ac.id
}

\begin{abstract}
Siak Regency, Riau Province is one of the most forest and land fireprone regencies in Indonesia. Most of the fires occur in peatland areas which contributes to the transboundary haze pollution in the region. Despite limited studies, fire severity assessment is an essential step in post-fire activities to estimate ecological impacts and economic impacts, and law enforcement. This study aimed to estimate fire severity using Sentinel-2 imagery at Siak Regency, Riau Province. The methods applied Normalized Burn Ratio on Sentinel-2 Imageries using Near-Infrared and Shortwave Infrared bands for 2019. The results indicated that the burned areas in Siak Regency were classified into four fire severity classes by difference Normalized Burn Ratio $(d N B R)$. The area was classified into low fire severity (16.34\%), moderatelow fire severity (4.96\%), moderate-high fire severity (0.89\%), and high fire severity (0.33\%). The high fire severity was found mainly at Sungai Apit District.
\end{abstract}

How to cite (CSE Style $8^{\text {th }}$ Edition):

Afina FS, Syaufina L, Sitanggang IS. 2021. Forest and peatland fire severity assessment at Siak Regency, Riau Province using Sentinel2 Imagery. JPSL 11(4): 621-630. http://dx.doi.org/10.29244/jpsl.11.4.621-630.

\section{INTRODUCTION}

Riau province is a peatland-dominated area in Indonesia covering 3.87 million ha, the largest in Sumatera. Approximately 2.31 million hectares of the peatland area have been degraded due to fires, water mismanagement, and mining activities (Masganti et al., 2014). The peatland fire always occurs annually and contributes to the region's transboundary haze pollution, closely related to an acute respiratory infection problem experienced by the community in some areas of the province (Syaufina and Hamzah, 2021). In 2019, the burned area in Riau Province covered 90550.00 ha (KLHK, 2019). Siak Regency, as one of the regencies in Riau Province, has been one contributor to the fire problem as it contributes $12.5 \%$ of the peatland area in the province.

The magnitude of the impact of fire on ecosystem elements and the environment depends on several factors: fire intensity, fire severity, soil type, rain that falls after the fire, and the extent of the fire (Syaufina and Ainuddin, 2011). One approach to identifying fires' impacts is the fire severity assessment, which measures the impacts of fires on vegetation and soil properties. This approach can be used for forest fire impact assessment as one of the activities in forest fire control. Forestry Law no. 41 of 1999 and Government Regulation Number 45 of 2004 on Forest Protection-Article 22, Article 23, Article 24, and Article 25 describe 
the importance of implementing forest fire control programs, including prevention, suppression, and post-fire management (Syaufina, 2017). Fire severity assessment in Indonesia seems to be limited in the implementation with several challenges.

Various fire severity assessment has been developed using field-level assessment and satellite data or spatial data approach. Assessing the impact of forest and land fires directly on the field is often constrained by places that are time-consuming and difficult to reach, therefore, the application of technology in assessing the impact of land fires needs to be further developed. Monitoring an area is now very easy and fast with the rapid development of technology every year because many tools and methods have been used, including remote sensing using satellite assistance (Que et al., 2019). The use of technology in assessing the impact of the fire is expected to produce accurate and compelling data to assess the impact of forest and land fires. Spatial analysis in forest and land fire research has been widely used, among others, to determine the classification of burned area, estimate the burned area, the impact of fires on land cover change, carbon emissions, peatland fire prediction, and haze trajectory (Maulana et al., 2019; Tantriawan et al., 2018; Hafni et al., 2018; Sitanggang et al., 2017; Thariqa et al., 2016).

Moreover, identification of burned areas can be approached by ground checking and hotspot analyses as a fire indicator. A hotspot is a term for a pixel with a temperature value above a certain threshold from the interpretation of satellite imagery, which can be used to indicate forest and land fires (KLHK, 2016). Hotspots are usually used as an indicator of the forest, and land fires in an area, an area with more hotspots, indicates a higher chance for forest and land fire to occur (Endrawati, 2016). However, not all hotspots are a strong indicator of forest and land fires. The incidence of hotspots in a sequence of at least three days in an adjacent location can strongly indicate land and forest fires occurrences (Syaufina and Sitanggang, 2018). Therefore, a clustered hotspot is probably valuable for verifying burned areas in spatial analyses. However, spatial analysis for fire impact assessment is still limited. This study aimed to estimate the severity of forest and peatland fires using the Difference Normalized Burn Ratio (dNBR) method on Sentinel-2 imagery at Siak Regency, Riau Province.

\section{METHODS}

\section{Study Area and Period}

This research was conducted from May to September 2021 in the study area of Siak Regency, Riau Province (Figure 1). Analysis and processing of image data were carried out at the Forest and Land Fire Laboratory, Faculty of Forestry and Environment, IPB University.

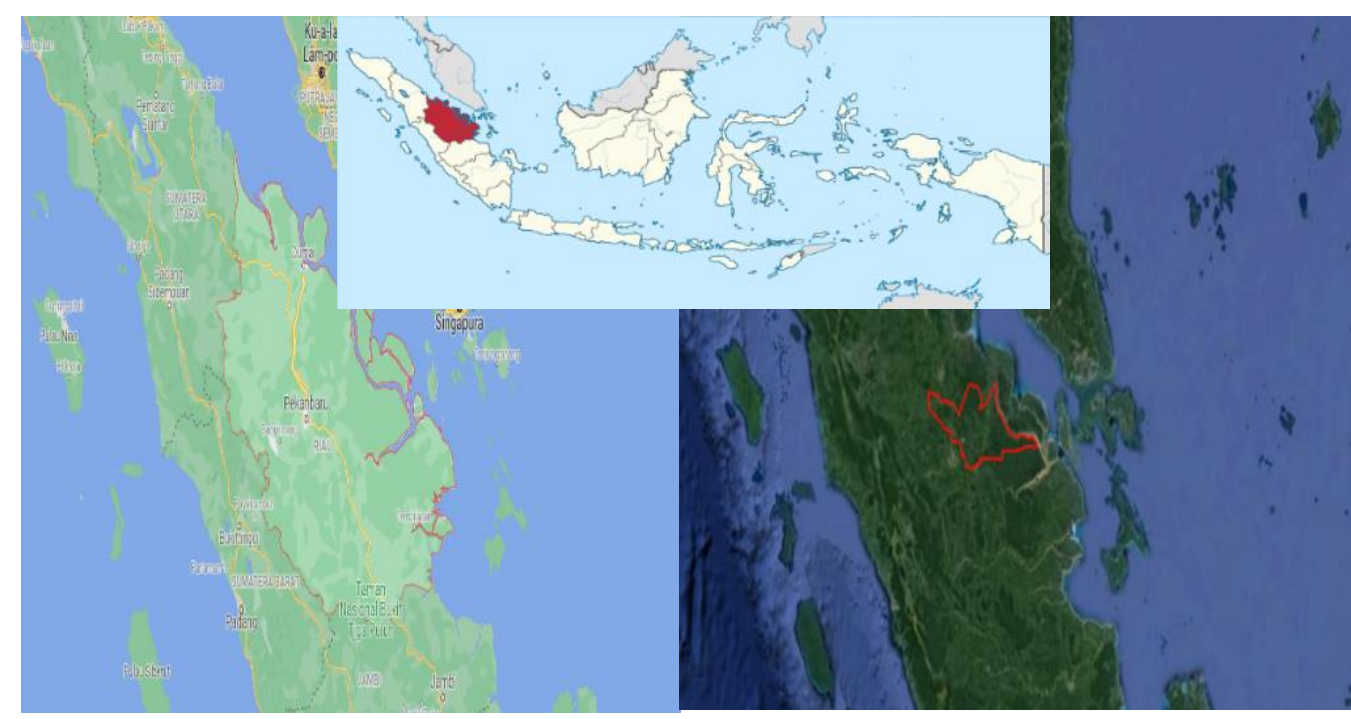

Figure 1 The study area of Siak Regency, Riau Province, Indonesia 
Siak Regency is a regency in Riau Province, covering $8556.09 \mathrm{~km}^{2}$ with a population of 457940

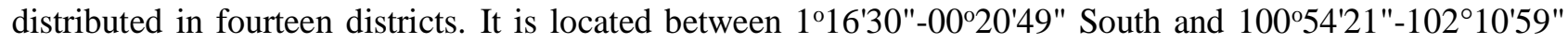
East, as a growth triangle of Indonesia-Malaysia-Singapura. The most landscape of Siak consists of lowland in the eastern part and highland in the western part, dominated by peatland area covering 484260 ha or about $56.6 \%$ of the total area. It is included in a tropical region with an average temperature of $25-32^{\circ} \mathrm{C}$ and high relative humidity and rainfall. Forest area covers $23.1 \%$, and plantation area covers $20.9 \%$ of the total area of Siak Regency. As peatland-dominated areas, forest and land fires have become common phenomena that occur annually in Siak, particularly in dry seasons. The study was focused on operational working area of Manggala Agni (DAOPS) Siak.

\section{Data Collection}

\section{Hotspot Data}

Hotspot data was used in this study to identify the image of the before burning period (Pre fire) and image after the burning period (Post-fire). Besides, the data was used as forest and land fires indicator for fire occurrences analyses. The hotspot data was derived from the LAPAN MODIS catalog of Moderate Resolution Imaging Spectroradiometer (MODIS) satellite imagery and Suomi National Polar-orbiting Partnership (SNPP) satellite for 2019. The confidence level shows that the hotspot monitored from remote sensing satellite data is genuinely an actual fire incident in the field (LAPAN, 2016). In this study, the confidence value used is $>80 \%$ (Table 1). The following are the confidence interval criteria according to Giglio et al., 2018):

Table 1 Confidence level of hotspot criteria

\begin{tabular}{cc}
\hline Percentage Range & Confidence Level \\
\hline $0 \% \leq \mathrm{C}<30 \%$ & Low \\
$30 \% \leq \mathrm{C}<80 \%$ & Nominal \\
$80 \% \leq \mathrm{C} \leq 100 \%$ & High \\
\hline
\end{tabular}

Where: C: confidence level

\section{Sentinel-2 Images}

The image used in this study is Sentinel-2 which is open-access imagery with higher spatial resolution than other infrared images. The Satellite imagery was downloaded from Copernicus Open Access Hub based on the results of hotspot data processing. We used satellite images of April 2019 for the Pre fire period and September 2019 for the Post-fire period.

\section{Data Analysis}

\section{Normalized Burn Ratio (NBR) Calculation}

The Normalized Burn Ratio (NBR) is designed to highlight burned areas and estimate fire severity (Que et al., 2019). The application of this method requires satellite image data before the forest and land fire and after the area burned (Saputra et al., 2017). Here is the equation to calculate the NBR:

$$
N B R=\frac{N I R-S W I R}{N I R+S W I R}
$$

Description:

NBR : Normalized Burn Ratio

NIR : Near-Infrared Spectral Band Value

SWIR: Short Wavelength Spectral Band Value 
The image used in this study is Sentinel-2. Near-Infrared (NIR) uses band 8A, and Shortwave Infrared (SWIR) uses band 12 (Table 2). NIR represents vegetation conditions, while SWIR is used for burned areas. The following is the equation for calculating NBR based on the United States Geological Survey (USGS):

$$
N B R=\frac{8 A-12}{8 A+12}
$$

Table 2 Applications of each band in Sentinel-2 image

\begin{tabular}{cccc}
\hline Band & Spectral Range & Wavelength $(\mu \mathrm{m})$ & $\begin{array}{c}\text { Spatial Resolution } \\
(\mathrm{m})\end{array}$ \\
\hline 1 & Aerosol & 0.443 & 60 \\
2 & Blue & 0.490 & 10 \\
3 & Green & 0.560 & 10 \\
4 & Red & 0.665 & 10 \\
5 & Red Edge 1 & 0.705 & 20 \\
6 & Red Edge 2 & 0.740 & 20 \\
7 & Red Edge 3 & 0.783 & 20 \\
8 & NIR & 0.842 & 10 \\
$8 \mathrm{~A}$ & Red Edge 4 & 0.865 & 20 \\
9 & Water vapour & 0.945 & 60 \\
10 & SWIR Cirrus & 1.357 & 60 \\
11 & SWIR & 1.610 & 20 \\
12 & SWIR $_{\mathrm{L}}$ & 2.190 & 20 \\
\hline
\end{tabular}

\section{Difference Normalized Burn Ratio (dNBR) Calculation}

The value of Difference Normalized Burn Ratio (dNBR) is the comparison result of the Pre fire and the Post-fire normalized burn ratio calculation. The dNBR value is then used to find the value of the severity of forest and land fires (Table 3). The higher the dNBR value, the higher the severity of the fire that occurs. On the contrary, if the resulting dNBR value is low, then the severity is low. The following is the equation for calculating dNBR based on the United States Geological Survey (USGS):

$$
\triangle N B R=\text { Pre fire } N B R-\text { Post fire } N B R
$$

Table 3 Fire severity criteria

\begin{tabular}{cc}
\hline Value & Description \\
\hline 0.1 & Unburned \\
0.27 & Low severity \\
0.44 & Moderate-Low Severity \\
0.66 & Moderate-High Severity \\
1.3 & High Severity \\
\hline
\end{tabular}

\section{RESULTS AND DISCUSSION}

\section{Hotspot Distribution}

Hotspot data were used in this study to identify the fire period for determining the Pre fire and Post-fire images. The image selection was conducted by identifying the highest hotspot period as a reference for the fires occurrences. The analysis indicates that Siak Regency experienced two fire seasons, namely FebruaryMarch and July-September. The highest hotspot was found in August (Figure 2) when the VIIRS sensor satellite image (SNPP satellite) recorded 767 hotspots, and the MODIS sensor satellite image recorded 104 624 
hotspots. In Siak, 104000 hectares were burned between 2003 and 2019, and 91\% or about 95000 hectares were burned consistently in February-March and June-August. Most fires occurred in scrubland and bareland, 54\% of fire hotspots from 2003 to 2019 in Siak occurred within lands considered unmanaged (Hapsari et al., 2020).

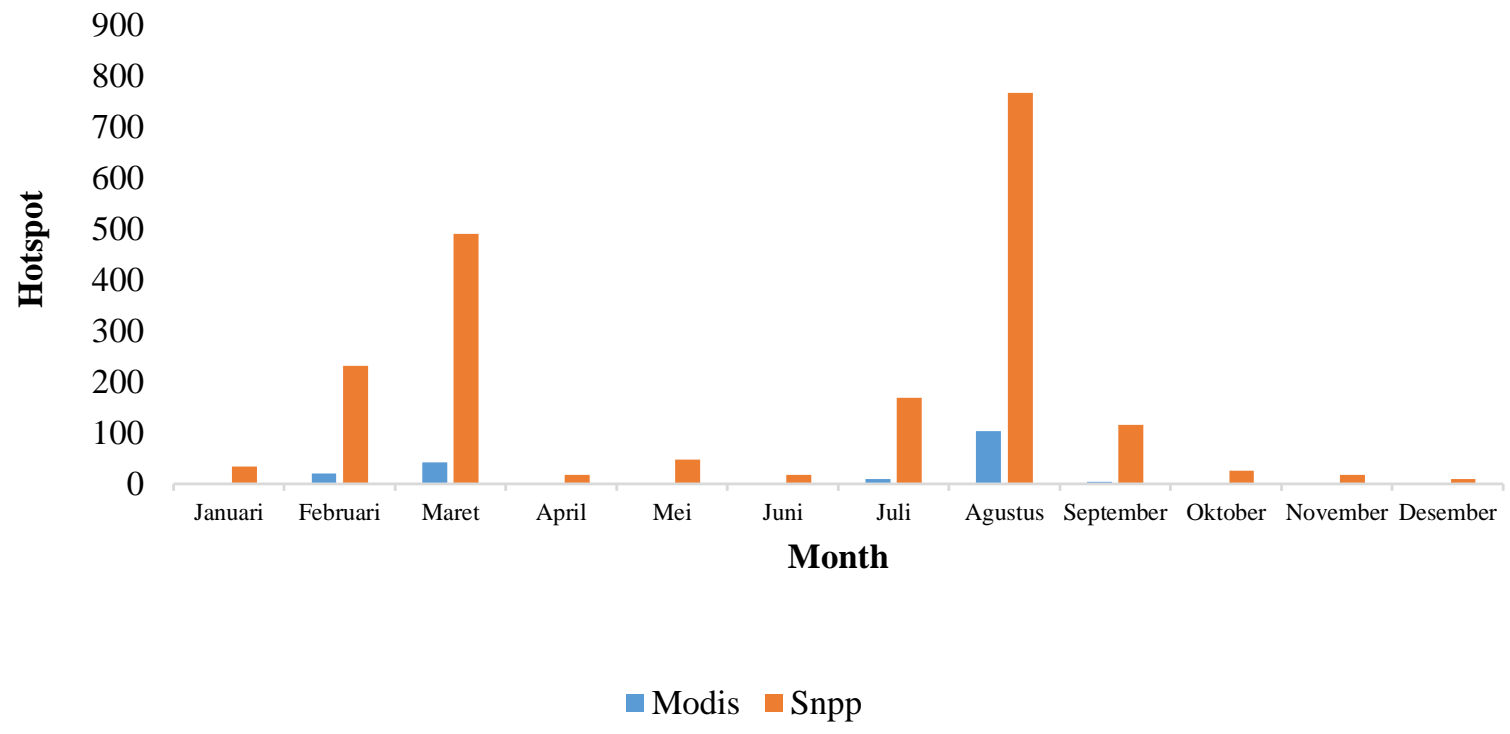

Figure 2 Monthly hotspot distribution of Siak Regency in 2019
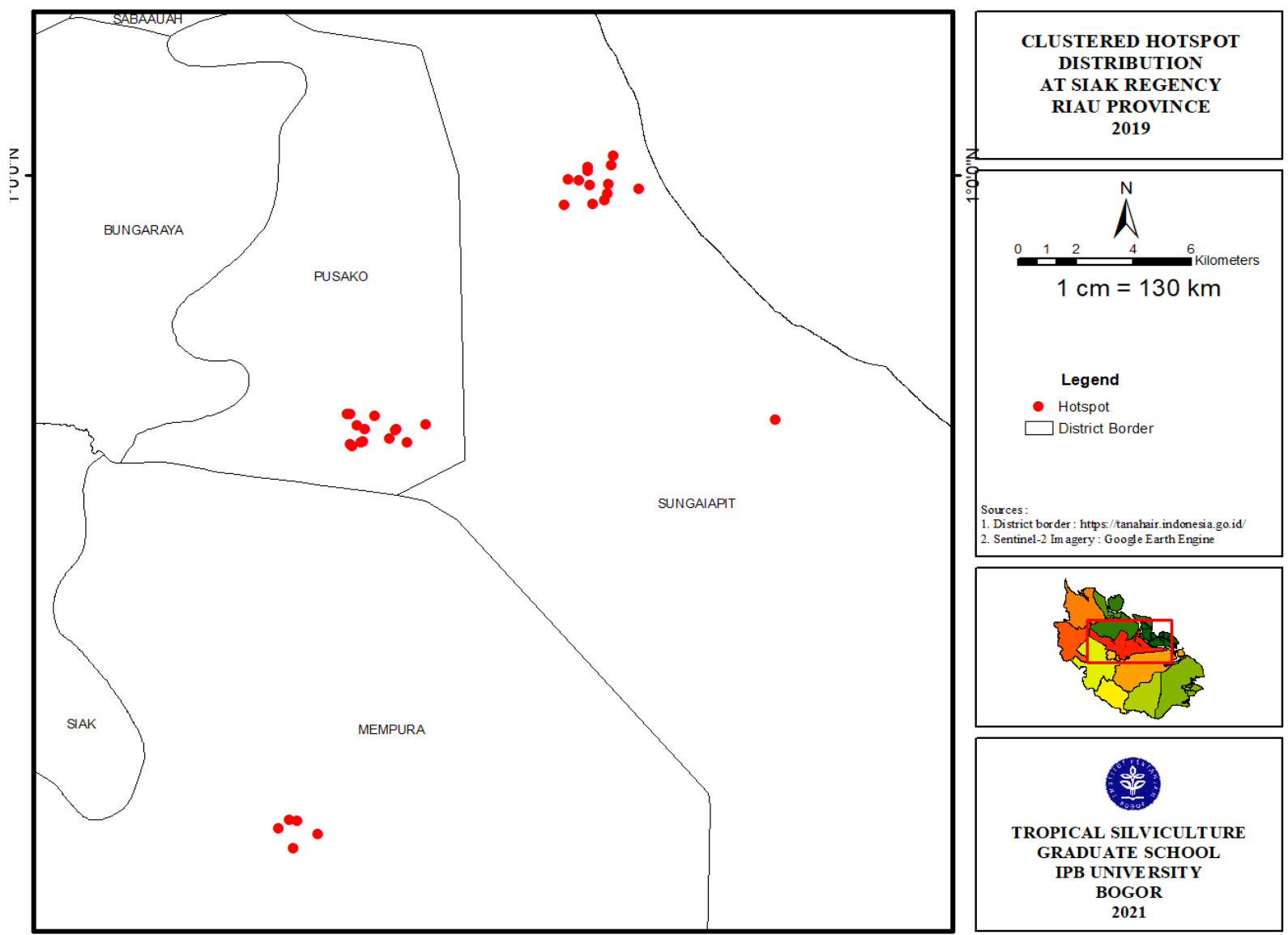

Figure 3 Clustered hotspot distribution at Siak Regency 
The confidence interval used is $>80 \%$, whereas the higher the confidence interval is, the higher the potential that the hotspot is an actual land or forest fire (LAPAN, 2016). In addition to using confidence intervals, the estimation of forest and land fires can be analyzed from hotspots clustering. A large fire is not commonly detected as only one hotspot as the heat radiation, and convection effect spreads to the surroundings. Therefore, the hotspot cluster is likely to be ascertained that land and forest fires occurred (LAPAN, 2016); information on the number of hotspots in estimating the burned area should use sequential data of hotspot detected for a minimum of 3 to 7 days during the fire period. Recent studies identify that clustered and sequential hotspots are a strong indicator for forest and land fire occurrences (Rezainy et al., 2020; Syaufina and Sitanggang, 2018; Kirana et al., 2015). Our spatial analyses show clustered hotspots as a strong indicator for forest and land fires occurrences (Figure 3).

\section{Forest and Land Fire Severity}

The Normalized Burn Ratio (NBR) value is used to identify the burned area. NBR calculation uses Near Infrared (NIR) wavelength, whereas Sentinel-2 imagery uses band 8A, and Shortwave Infrared (SWIR) uses band 12. Normalized Burn Ratio (NBR) calculation requires Prefire images and Post-fire images. Determination of the image before and after the forest and land fire can use the distribution of hotspots to indicate the occurrence of a land fire. Based on the Sentinel-2 RGB image composite (12, 8A, 4), the image's colour changes can be seen before and after the fire (Figure 4). Image composite is a process that combines three bands in the image to get red, green and blue colours. The results obtained showed a change in the colour hue in the image after the fire. The NBR was better used to extract burned area rather than NDVI or a single spectral band (Prasasti and Triyono, 2020). According to Hafni et al. (2018), the burned area is visually indicated by: (1) reddish-brown colour, and the colour is darker than that of the surrounding area; (2) the shape of the burned area is generally a rectangular polygon; (3) the size of the burned area ranges from 0.87-216.49 ha; (4) the pattern is irregular; (5) the texture is smooth; (6) the location of the burned area is generally land cover in the form of shrubs, oil palm plantations, plantation forests, and secondary forests; (7) associated with the presence of roads and canals.

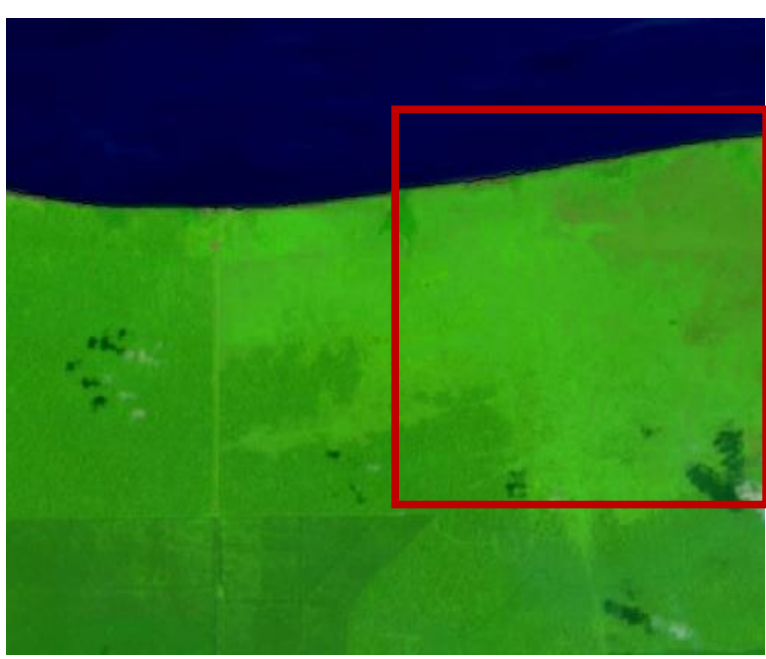

(a)

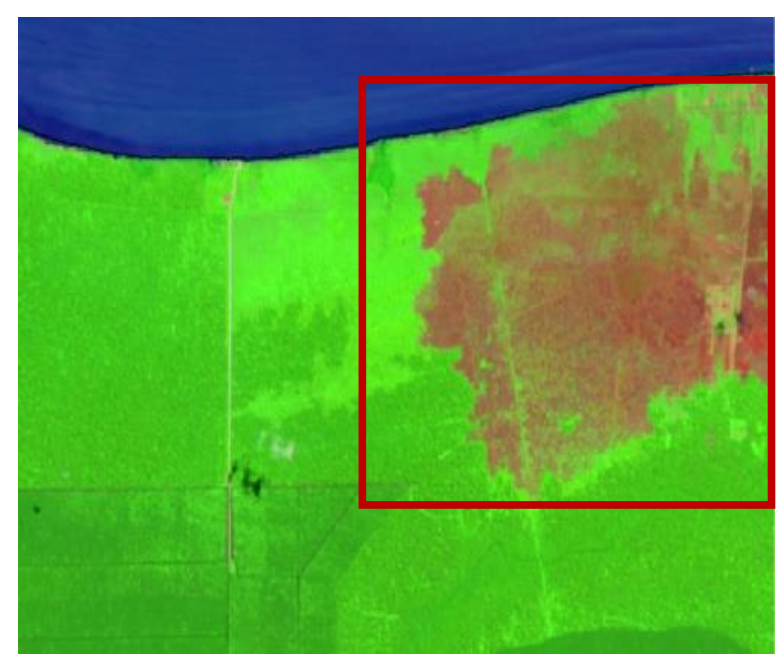

(b)

Figure 4 Image of Sentinel-2 RGB composite (12, 8A, 4) in Siak Regency in 2019

(a) Pre fire image, (b) Post-fire image

Different studies suggested that the NBRb12 (short-wave infrared 2-SWIR2) produced the best results for detecting burnt areas. SAM resulted in a 73\% overall accuracy in thematic mapping, and Sentinel-2 can be used to discern burned areas and burning severity (Amos et al., 2019). Predictive local thresholds of dNBR values showed slightly higher classification accuracy for Sentinel 2A (73.33\%) than Landsat-8 OLI (71.11\%), 
suggesting the adequacy of Sentinel 2A for forest fire severity assessment and mapping in Mediterranean pine ecosystems (Mallinis et al., 2018). Fire severity can be mapped with very high accuracy using Sentinel 2 imagery, and RF supervised classification. The mean accuracy was $>95 \%$ for the unburnt and extreme severity class (total crown consumption), $>85 \%$ for high severity class (full crown scorch), $>80 \%$ for low severity (burnt understory, unburnt canopy) and $>70 \%$ for the moderate severity class (partial canopy scorch) (Gibson et al., 2020). Higher canopy cover and higher topographic complexity were associated with a higher rate of under-prediction due to the limitations of optical sensors in viewing the burnt understorey of low severity classes under these conditions (Gibson et al., 2020). The area burned estimated using the Sentinel 2A data is more accurate, which can be justified by the higher spatial resolution of this data (Teodoro and Amaral, 2019). Nevertheless, the optimal spectral index for quantifying fire severity varies with forest type. Still, there is scope to group forests by structure and fire-regeneration strategy to simplify fire-severity classification in heterogeneous forest landscapes (Tran et al., 2018). Besides, Recovery rates were generally most excellent for several years following the fire. Recovery in terms of percent NBR was often more significant for higherseverity patches. Recovery rates varied between forest types, with conifer-oak-chaparral showing the most excellent NBR recovery rates, mixed conifer showing intermediate rates, and ponderosa pine showing the slowest rates (Bright et al., 2019).

The Difference Normalized Burn Ratio (dNBR) value is used to estimate the forest and land fires severity. A high dNBR value indicates severe damage, and a low dNBR value indicates a high vegetation growth rate after the area is burned. Calculation of dNBR is the difference in value between the Pre fire NBR with the Post-fire NBR. Fire severity in resprouter open forests and woodlands was most accurately mapped using the delta Normalised Burnt ratio (dNBR) (Tran et al., 2018). The analyses resulted in four fire severity classes in Siak Regency Low severity, moderate-low severity, moderate-high severity, and high severity. Forest and land fire in Siak is dominated by low fire severity area (79 106 ha), followed by moderate-low severity area (24 $036 \mathrm{ha}$ ), moderate-high severity area (4 319 ha), high severity area (1 $613 \mathrm{ha})$, and unburned area (375 $191 \mathrm{ha})$ (Table 4).

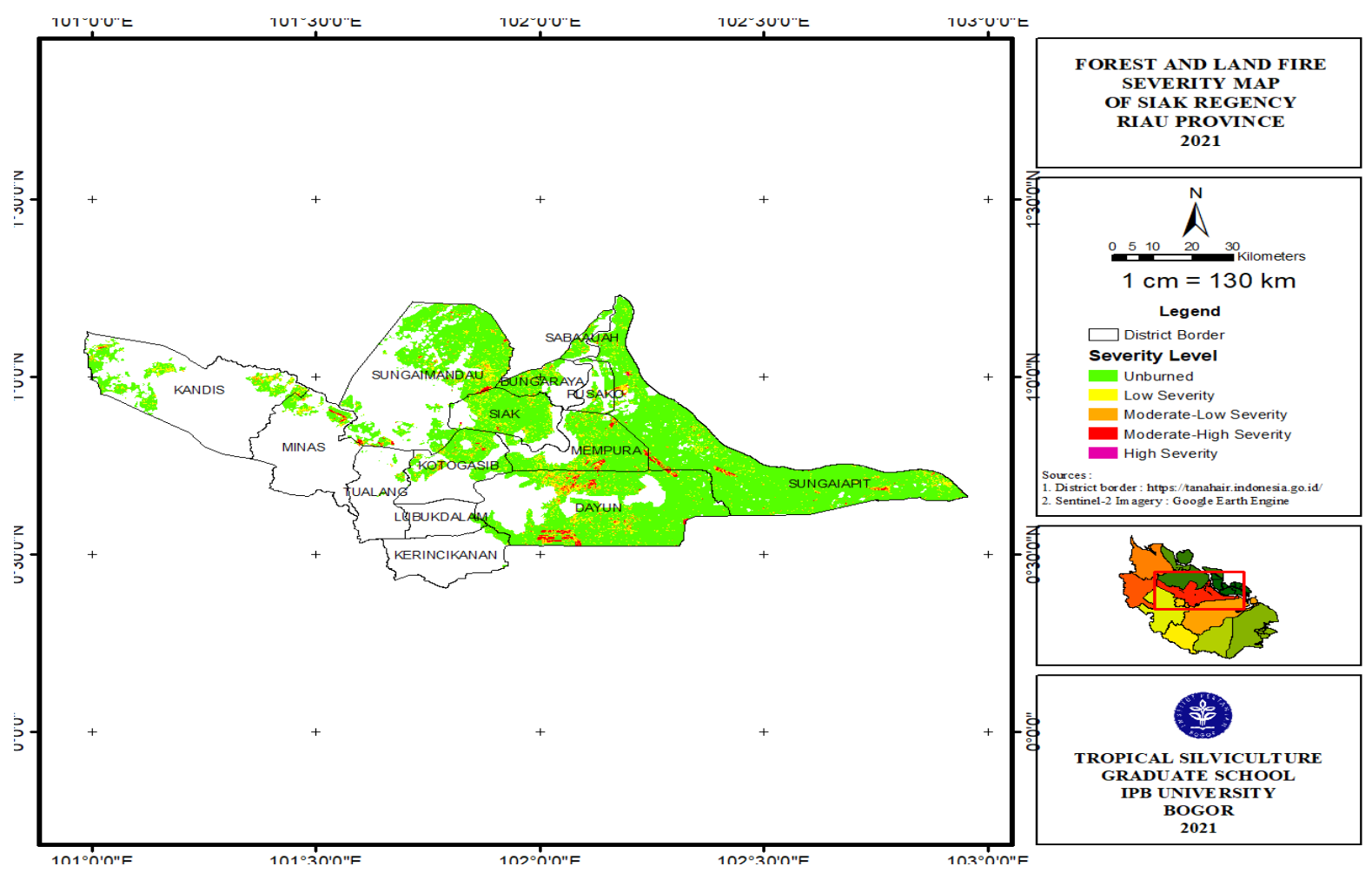

Figure 5 Map of the severity of peatland fires in Siak Regency, Riau Province in 2019 
Spatial distribution of the forest and land fire severity on peatland area at Siak Regency, Riau Province is characterized in various colours. Low severity is yellow, moderate-low severity is orange, moderate-high severity is red, high severity is purple, and the unburned area is green (Figure 5). The burned area mainly was found at Sungai Apit and Mempura Districts, as found by other studies (Nurjanah and Sakir, 2021; Widodo et al., 2018). Moreover, Siak Regency has 13 Disaster-prone Districts and 71 Disaster-prone Villages. Districts that are prone to disasters include Siak, Sungai Apit, Minas, Kandis, Lubuh Dalam, Kerinci Kanan, Koto Gasib, Tualang, Sungai Mandau, Dayun, Bungraya, Mempura, Sabak Auh, Pusako districts. The most considerable contribution to disaster-prone villages is in the Sungai Apit District, which consists of 14 disaster-prone villages (Nurjanah and Sakir, 2021). Forest fire in peatland areas is mainly contributed by dry peat condition, which is influenced by groundwater table condition (Widodo et al., 2019). Peat fires on community land occur primarily during the dry season. The burning of peatland is generally a practice used for land clearing. Socalled slash-and-burn practices for land clearing is preferred because it is cheap, and the leftover ash serves as a fertilizer for the peat soil (Wasis et al., 2019).

Table 4 Forest and land fire severity classification at Siak Regency in 2019

\begin{tabular}{ccc}
\hline Fire Severity Classes/Condition & Area (ha) & Percentage (\%) \\
\hline Unburned & 375191.63 & 77.34 \\
Low severity & 79106.00 & 16.34 \\
Moderate-Low Severity & 24036.00 & 4.96 \\
Moderate-High Severity & 4319.00 & 0.89 \\
High Severity & 1613.00 & 0.33 \\
\hline
\end{tabular}

\section{CONCLUSION}

Siak Regency has two fire seasons, namely February-March and July-September, with the peak in August. Clustering hotspots can be used as solid indicators for fire occurrences. The spatial analyses using Normalized Burn Ratio on Sentinel-2 Imageries using Near-Infrared and Shortwave Infrared bands are appropriate for peatland fire severity classification. The analyses showed that peatland fire in Siak Regency was classified into four classes of fire severity, which was dominated by the low fire severity $(16.34 \%)$, followed by moderate to low severity $(4.96 \%)$, moderate to high severity $(0.89 \%)$ and high fire severity $(0.33 \%)$. The majority of fire occurred in Sungai Apit and Mempura Districts with high severity class found in Sungai Apit District.

\section{ACKNOWLEDGEMENTS}

The authors wish to thank The Ministry of Education, Culture, Research and Technology for financial support through The Master Thesis Research Scheme (PTM) and to The Laboratory of Forest and Land Fire, Department of Silviculture, Faculty of Forestry and Environment, IPB.

\section{REFERENCES}

[KLHK] Kementerian Lingkungan Hidup dan Kehutanan. 2016. Peraturan Menteri Lingkungan Hidup dan Kehutanan Republik Indonesia Nomor: P.32/MenLHK/Setjen/Kum.1/3/2016 Tentang Pengendalian Kebakaran Hutan dan Lahan. Jakarta (ID): KLHK.

[KLHK] Kementerian Lingkungan Hidup dan Kehutanan. 2019. Karhutla Monitoring Sistem [Internet]. [Downloaded 2021 Jan 15]. Available at: http://sipongi.menlhk.go.id/hotspot/luas_kebakaran.

[LAPAN] Lembaga Penerbangan dan Antariksa Nasional. 2016. Informasi Titik Panas (Hotspot) Kebakaran Hutan atau Lahan. Jakarta (ID): Deputi Bidang Penginderaan Jauh-LAPAN.

Amos C, Petropoulos GP, Ferentinos KP. 2019. Determining the use of Sentinel-2A MSI for wildfire burning $\&$ severity detection. International journal of remote sensing. 40(3): 905-930. 
Bright BC, Hudak AT, Kennedy RE, Braaten JD, Khalyani AH. 2019. Examining post-fire vegetation recovery with Landsat time series analysis in three western North American forest types. Fire Ecology. 15(1): 114.

Endrawati. 2016. Analisis Data Titik Panas (Hotspot) dan Areal Kebakaran Hutan dan Lahan tahun 2016. Jakarta (ID): Ditjen Planologi Kehutanan dan Tata Lingkungan Kementerian Lingkungan Hidup dan Kehutanan.

Gibson R, Danaher T, Hehir W, Collins L. 2020. A remote sensing approach to mapping fire severity in southeastern Australia using sentinel 2 and random forest. Remote Sensing of Environment. 240: 111702111715 .

Giglio L, Schroeder W, Hall JV, Justice CO. 2018. MODIS Collection 6 Active Fire Product User's Guide Revision $B$. Washington DC (US): NASA.

Hafni DAF, Syaufina L, Puspaningsih N, Prasasti I. 2018. Estimation of carbon emission from peatland fires using Landsat-8 OLI imagery in Siak District, Riau Province. IOP Conference Series: Earth and Environmental Science. 149(1): 1-10.

Hapsari D, Nainggolan O, Kusuma D. 2020. Hotspots and regional variation in smoking prevelance among 514 Districts in Indonesia: Analysis of basic health research 2018. Global Jurnal of Health Science. 12(10): 32-44.

Kirana AP, Sitanggang IS, Syaufina L. 2015. Poisson clustering process on hotspot in peatland area in Sumatera. Telkomnika. 13(4): 1376-1383.

Mallinis G, Mitsopoulos I, Chrysafi I. 2018. Evaluating and comparing Sentinel 2A and Landsat-8 Operational Land Imager (OLI) spectral indices for estimating fire severity in a Mediterranean pine ecosystem of Greece. GIScience \& Remote Sensing. 55(1): 1-18.

Masganti, Wahyunto, Dariah A, Nurhayati, Yusuf R. 2014. Characteristics and potential utilization of degraded peatlands in Riau Province. Jurnal Sumberdaya Lahan. 8(1): 59-66.

Maulana SI, Syaufina L, Prasetyo LB, Aidi MN. 2019. Spatial logistic regression models for predicting peatland fire in Bengkalis Regency, Indonesia. Journal of Sustainability Science and Management. 14(3): 55-66.

Nurjanah A, Sakir AI. 2021. The role of Masyarakat Peduli Api (MPA) communities in forest and land fire disaster communication in Riau Province. 4th International Conference on Sustainable Innovation 2020-Social, Humanity, and Education (ICoSIHESS 2020). 518: 203-210.

Prasasti I, Triyono D. 2020. Detecting the burned area in volcanic region by using multitemporal Landsat-8 OLI (Case Study: Mt. Sumbing, Central Java). Journal of Physics: Conference Series. 1577(012017): $1-5$.

Que VKS, Prasetyo SYJ, Fibriani C. 2019. Analisis perbedaan indeks vegetasi normalized vegetation index (NDVI) dan normalized burn ratio (NBR) Kabupaten Pelalawan menggunakan citra satelit landsat 8. Indonesian Journal of Modeling and Computing. 1: 1-7.

Rezainy A, Syaufina L, Sitanggang IS. 2020. Pemetaan daerah rawan kebakaran di lahan gambut berdasarkan pola sekuens titik panas di Kabupaten Pulang Pisau Kalimantan Tengah. Jurnal Pengelolaan Sumberdaya Alam dan Lingkungan (Journal of Natural Resources and Environmental Management). 10(1): 66-76.

Saputra AD, Setiabudidaya D, Setyawan D, Iskandar I. 2017. Validasi areal terbakar dengan metode normalized burning ratio menggunakan UAV (Unmanned Aerial Vehicle). Jurnal Penelitian Sains. 19(2): 66-72.

Sitanggang IS, Asti AD, Syaufina L, Khotimah H. 2017. Haze trajectory clusters in South Sumatra in 2015 a simulation using Opentraj. 2017 International Conference on Electrical Engineering and Computer Science (ICECOS); 2017 Aug 22-23; Palembang, Indonesia. Palembang (ID): IEEE. p 149-153. 
Syaufina L, Hamzah AA. 2021. Changes of tree species diversity in peatland impacted by moderate fire severity at Teluk Meranti, Pelalawan, Riau Province, Indonesia. Biodiversitas Journal of Biological Diversity. 22(5): 2899-2908.

Syaufina L, Sitanggang IS. 2018. Peatland fire detection using spatio-temporal data mining analysis in Kalimantan, Indonesia. Journal of Tropical Forest Science. 30(2): 154-162.

Syaufina L. 2017. Metode Penilaian Areal Pasca Kebakaran Hutan. Bogor (ID): IPB Press.

Syaufina L, Ainuddin AN. 2011. Impacts of fire on south east asia tropical forests biodiversity: A review. Asian Journal of Plant Sciences. 10(4): 238-244.

Tantriawan H, Sitanggang IS, Syaufina L, Harsa H. 2018. Temporal prediction of carbon monoxide using the Elman Recurrent Neural Network. IOP Conference Series: Earth and Environmental Science. 203(012040): 1-8.

Teodoro A, Amaral A. 2019. A statistical and spatial analysis of Portuguese forest fires in summer 2016 considering Landsat 8 and Sentinel 2A data. Environments. 6(3): 1-17.

Thariqa P, Sitanggang IS, Syaufina L. 2016. Comparative analysis of spatial decision tree algorithms for burned area of peatland in Rokan Hilir Riau. TELKOMNIKA. 14(2): 684-691.

Tran BN, Tanase MA, Bennett LT, Aponte C. 2018. Evaluation of spectral indices for assessing fire severity in Australian temperate forests. Remote Sensing. 10(11): 1-8.

Wasis B, Saharjo BH, Putra EI. 2019. Impacts of peat fire on soil flora and fauna, soil properties and environmental damage in Riau Province, Indonesia. Biodiversitas Journal of Biological Diversity. 20(6): 40-44.

Widodo J, Izumi Y, Takahashi A, Kausarian H, Kuze H, Sumantyo JTS. 2018. Detection of dry-flammable peatland area by using backscattering coefficient information of ALOS-2 data L-band frequency. 2018 Progress in Electromagnetics Research Symposium (PIERS-Toyama); 2018 Aug 1-4; Toyama, Japan. Japan (JP): 916-920. 